\title{
On the Buddha Posture in Heart of Darkness
}

\author{
Hong Gao \\ School of Foreign Studies \\ East China University of Political Science and Law \\ Shanghai, China \\ Email: sapphiregao@126.com
}

\begin{abstract}
The elusive Buddha postures of Marlow Conrad has crafted in Heart of Darkness have manifold literary values. Aside from resonating with the structure of the story, they also project the theme of disillusion and allude to the Buddhist solution to the crisis of material worship prevailing the west around the 1900s.
\end{abstract}

Keywords: Conrad; Buddha; Marlow; Kurtz; preaching; veils of Maja

\section{INTRODUCTION}

In Heart of Darkness there are three passages in which Marlow's physical appearance is likened to that of the Buddha:

Marlow sat cross-legged right aft, leaning against the mizzen-mast. He had sunken cheeks, a yellowish complexion, a straight back, and ascetic aspect, and with his arms dropped, the palms of hand outwards, resembled an idol. (Conrad, p.15)

"Mind," he began again, lifting one arm from the elbow, the palm of the hand outwards, so that with his legs folded before him he had the pose of a Buddha preaching in European clothes and without a lotus-flower......(Conrad,p.18)

Marlow ceased, and sat apart, indistinct and silent, in the pose of a meditating Buddha. (Conrad, p.97-98)

What message does Conrad attempt to convey to the reader through these three passages?

This paper holds that the passages depicting Marlow's Buddha posture have at least two functions. First, the three passages are carefully placed with abundant meaning. Second, through likening his hero to the Buddha instead of God in the three quotations, Conrad implicitly announces at once his attitudes towards Christianity and Buddhism and his philosophical outlook on life. This implicit announcement, if correctly construed, will help the reader understand the story better.

\section{CONRAD AND BUDDHISM}

In his Author's Note Conrad wrote that, compared to Youth, Heart of Darkness is "experience, too; but it is experience pushed a little (and only very little) beyond the actual facts of the case for the perfectly legitimate, I believe, purpose of bring it home to the minds and bosoms of the readers. " (Watt, p.141) Here the experience on which Heart of
Darkness is based obviously refers to Conrad's journey in 1890 in Africa up the Congo River.

Before going to Africa, Conrad, like his hero Marlow in Heart of Darkness, "just returned to London after a lot of Indian Ocean, Pacific, China seas." (Conrad, p.19) All these travels to the eastern countries suffice to offer Conrad opportunities to be familiar with the various sitting postures of the monks, their meaning, and possibly the relevant stories as well as teachings of the Buddha.

The Congo journey in some sense enlightens Conrad and makes him thirsty for a spiritual refuge. This may account for his zeal for Schopenhauer who discussed at length the philosophies of the Orient in The World As Will and Idea. According to John Galsworthy, Schopenhauer was a particular object of interest to Conrad at the turn of the century and "used to give him satisfaction. "(Galsworthy, p.121) Arthur Schopenhauer (1788-1860), a famous German philosopher, was very interested in Buddhism, and the ancient Indian philosophy is one the main sources of his philosophy. In his book, Schopenhauer once and again quotes the Indian philosophical term "veil of Maja ", which means the veil of illusions, to explain the illusion and suffering of life ,and advocates that only be seeing through the veil of illusion can people get rid of the pains of life $(\mathrm{Li}$, p.3), which is exactly the idea of Buddhism.

\section{THE AsSOCIATION OF THE BUDDHA POSTURE WITH THE DEVELOPMENT OF THE STORY}

By using the Buddha tableaux, Conrad may be deliberate in drawing on it to make the development of his story smooth and natural. Then how does the careful choice of details of the Buddha posture in the three quotations lead a sequential development of the story as a whole?

This paper suggests earlier that Heart of Darkness is somewhat based on Conrad's personal experience in Africa up the Congo River and in some sense Conrad is Marlow in Heart of Darkness. Having experienced both mental and physical traumas, Conrad or his hero Marlow seem to get something from the indelible experiences. Bearing this background in mind, the reader, while reading the story, will undoubtedly see that Joseph Conrad is actually reflecting and reliving his own life with the character Marlow in his novel. The very first passage quoted above brings all this clearly to the reader. The posture adopted by Marlow in the first 
quotation is that of the Buddha at the moment of his enlightenment. In the story of the Buddha, Siddhartha Gautama, after a life of luxury and the extremes of asceticism, went to sit down beneath the branches of the Bodhi Tree in a seclude grove. In this quoted passage, Marlow is described as "leaning against the mizzen-mast ". Here the mizzen-mast is obviously compared to the Bodhi Tree by Conrad. Though the unnamed primary narrator does not mention the Buddha by name, he does say that Marlow "resembled an idol. " in countless idols and painting, only the Buddha is depicted with his arms dropped while meditating.

In the Buddha story, the Buddha, after his enlightenment, for a time doubted whether he should proclaim his wisdom to the world, as it was so recondite and difficult to express, but ultimately he did go to the place where his five former disciples had settled and to these five ascetics the Buddha preached his first sermon. On this story of the Buddha, Conrad draws to organize his story. For presumably this is the first time Marlow is telling his story to his four listeners. After his return from Africa, he is unwilling or unable for a while to communicate with anyone. But that day at dusk on board the Nellie comes in sight the scene: "The day was ending in a serenity of still and exquisite brilliance. The water shone pacifically; the sky, without a speck, was a benign immensity of unstained light... Only the gloom to the west, brooding over the upper reaches, became more somber every minute, as if angered by the approach of the sun." (Conrad, p.15-16) The scene renders the five persons feeling "meditative (Conrad, p.16) "and send Marlow into reflecting his indelible experiences in the African Congo and the true knowledge he has attained there. William Bysshe Stein points out that: "Marlow's lotus posture shows he is ready to engage in an exercise of intense introspection; he is ready to contemplate the chaos out of which order or cosmos comes."(Kimbrough, p.197) Like Buddha, after the deep meditation and finally the enlightenment, Marlow feels that it is the right time to preach to his friends. So when Marlow tells his white fellows on board the ship his experiences in Africa, it seems quite natural in the sense of story development.

In the second quotation, the nonmystical aspect of Marlow is stressed through the description that he is wearing European clothes and that the symbolic lotus flower is not there under him. By this purposeful description, Conrad may want to hint to the reader that Marlow is an ordinary man and his story is only his personal experiences. But the posture used by Marlow in this passage does show that Marlow is serious in telling the story and that Marlow regards his personal experiences to be of some value in enlightening people and therefore worthy of telling. This is because the description of Marlow's gesture is a precise description of one that the Buddha used frequently: the gesture of assurance for audiences listening to his sermons. So by saying that Marlow has "the pose of a Buddha preaching ", Conrad hints that Marlow's story is going to be a sermon for his audience of four. This careful description convinces the reader of the seriousness of Marlow and the truthfulness of the story.

The first and second quoted passages contain descriptions of specific hand gestures, but at the end of the story, when Marlow's sermon is over, he no longer needs to convey a specific verbal message. His whole body is now in the posture of deep meditation. Silence is stressed in the third passage because silence is essential for the ritual Austerity of the Buddha's meditation. His sitting apart from the others is also emphasized because, traditionally, deep meditation (in contrast to the preaching Buddha that Marlow represented earlier) detaches himself from the noisy, verbal transaction of mankind.

\section{REALITY BEHIND THE VEILS OF MAJA}

\section{A. Reality Behind the First Veil of Maja}

From the very beginning of the story, Conrad establishes a comparison between Marlow the Buddhism believer and the westerners who believe in personal perfection from without. While "the lawyer had the only cushion on deck and was lying on the only rug" and "the accountant had brought out a box of dominoes and was toying architecturally with the bones" (Conrad, p.15), Marlow's Buddha sitting posture (in the first quotation ) gives evidence of his selfmortification and his denial of the tyranny of physical matter. Then Conrad tells the reader the different reactions of Marlow and his fellow whites on board the Nellie to the grand view of the profound serenity of the sky just before the sun vanishes under the horizon illumination the seaward reaches of the Thames. To the other four whites, the sight evokes "abiding memories " of the countless voyagers who set out from the Thames, and especially of the explorers with their famous "ships whose names are like jewels flashing in the night of time, "and of the colonizers who bore "the sword, and often the torch, messengers of the might within the land, bearers of a spark from the scared fire." To them, they were carrying "the dreams of men, the seed of commonwealth, the germs of empires." (Conrad, p.16) But the same sight only makes Marlow think of the cruel Roman Empire expansion for wealth — — "They grabbed what they could get... It was just robbery with violence, aggravated murder..., and men going at it blind", (Conrad, p.19) and the conflict inside the individuals who went blind into the wilderness "to mend his fortunes" (Conrad, p.18) only to be unfortunately lost there. This prefigures the fortunes of the whites in Africa, especially the fate of Kurtz, the highest representative of Western belief in material progress.

According to Arthur Schopenhauer, Conrad's favorite, "behind the veil of Maja (Sanskrit, means delusion and illusion), what we find is not God, but Satan." (Zhaowu, p.309)

Before Marlow sets out for Africa, "there had been a lot of such lot let loose in print and talk just about that time" as the whites going to Africa are "workers... Something like an emissary of light, something like a lower sort of apostle" to 
wean "those ignorant millions from their horrid ways."(Conrad, p25)

But while in Africa, behind the veil of Maja, Marlow does not see how the whites bring light and civilization to the natives; on the contrary, he only sees all the absurdities, cruelties done by the apathetic whites who go there only for resources and money and therefore somewhat are lost there.

The only purpose of the whites in Africa is to obtain resources and money. On his overland journey to the central station, Marlow has to look after a white companion who is "rather too fleshy and with the exasperating habit of fainting on the hot hillsides, miles away from the least bit of shade and water". (Conrad, p.33) Marlow couldn't help asking him once what he meant by coming here at all. "To make money, of course. What do you think?" he said, scornfully. (Conrad, p.33) When Marlow arrives at the central station he soon learns that this is indeed the only faith to be found among the colonizers. What preoccupies their mind is to make money and get ivory, just as Marlow comments: "they are all waiting - - all the sixteen or twenty pilgrims of them- for something." What is that something? The whites in the central station "wandered here and there... like a lot of faithless pilgrims bewitched inside a rotten fence. The word ' ivory' rang in the air, was whispered, was sighed... they were praying to it." (Conrad, p.37) So the something they are waiting for is the opportunity to get ivory. The idea of obtaining wealth occupies their mind so completely that there is no room left for their self, and with an obsessed mind they are deprived of the means to get in touch with the reality of life. They are in some sense lost in Africa. And with a bewitched mind, they do things just like in dreams and what they do seems to any person with a clear mind quite absurd and apathetic.

As Marlow observes with a clear mind, while on the way to the Congo River, he has seen absurdities everywhere: a French man-of-war shelling an apparently uninhabited forested stretch of coast where they claim "enemies " were hiding " out of sight somewhere"; (Conrad, p.27) at the central station the brickmaker makes no bricks; the man in black moustache fights the fire by filling his leaking bucket with " about a quart of water"; (Conrad, p.37) and the colonizers like real pilgrims with staves in their hand "strolling aimlessly about" (Conrad, p.37)

With only money in their mind, the whites in Africa become cruel and apathetic. If those native black people who could have lived normally in their own land do not work well under pressure for the white' s convenience to get ivory, they will be "called animals, and the outraged law" (Conrad, p.29) and punished, what Marlow encounters is "six black men advanced in file, toiling up the path. They walked erect and slow, balancing small baskets full of earth on their heads... each had an iron collar on his neck, and all were connected together with a chain whose bights swung between them." (Conrad, p.28) They are terribly emaciated, physically and psychologically overwrought, and are clothed in nothing but black rags. And those blacks who perform to the whites' satisfaction but "sickened and became inefficient" due to "unfamiliar food and uncongenial surrounding" are just "allowed to crawl away" (Conrad, p.30) and wait for death. Marlow, when intending to find a little shade, wanders into a grove. What he finds there appalls him: "Black shapes crouched, lay, sat between the trees leaning against the trunks, clinging to the earth, half coming out, half effaced with the dim light, in all the attitudes of pain, abandonment, and despair."(Conrad, p.28) They are slowly dying. While Marlow is appalled by the ghastly, infernal spectacle of the grove of death and find "nothing else to do but to offer one of them ——almost a boy_— my good Swede's ships biscuits I had in my pocket" (Conrad, p.28-30), the other colonizers show no concern and compassion over them at all.

With only money in mind, the whites are not only cruel to the blacks, but they are indifferent to the lot of their fellow whites as well. The chief accountant the company station,though looks like a walking "miracle" with his "high starched collar...cuffs...light alpaca jacket, snowy trousers...clear necktie, and varnished boots", says of the groans of the dying agent, with whom he is required temporarily to share his office, "distract my attention. And without that, it is difficult to guard against clerical errors in this climate." (Conrad, p.31-32)

If one' $s$ mind is only filled with greed for wealth and power, one will not be able to find his self and therefore cannot see the reality, and his management of a place will be embodied by chaos. "The flabby, pretending, weak-eyed devil of a rapacious and pitiless folly" (Conrad, p.29) is one of the central images with which Marlow characterizes the behaviour of the colonists. The band of the "flabby devil" is apparent in the travesties of administration and the widespread decay in the Company's stations. The colonials in the coastal station spend all their time blasting a cliff for no apparent reason, machinery lies broken all around, and supplies are poorly apportioned, resting in abundance where they are not needed and never sent to where they are urgently required. And when Marlow finally arrives at the central station, he sees "It was on a backwater surrounded by scrub and forest, with a pretty border of smelly mud on one side, and on the three others enclosed by a crazy fence of bushes. A neglected gap was all the gate it had, and the first glance at the place was enough to let you see the flabby devil was running that show." (Conrad, p.34)

All this is what Marlow sees in person on his journey in Africa. With his own eye, more important, with his clear mind, he sees the truth behind the veil of Maja - - the imperialism rhetoric "let loose in print and talk just about that time". Among those with troubled minds he alone possesses a clear mind because he is not after money and therefore he can find his self which allows him to have a direct talk with truth and reality. Just as Buddhism stresses: True wisdom is not simply believing what we are told but instead experiencing and understanding truth and reality. Wisdom requires an open, objective, unbigoted mind, which Marlow 
has and makes use of in his experiencing and understanding the reality to reach true wisdom.

\section{B. Reality Behind the Second Veil of Maja}

The introduction of the protagonist Kurtz is gradual, and the whole process is just like another veil of Maja being gradually cast before Marlow. In other words, Marlow's first acquaintance with Kurtz Is not through some direct contact with the person himself, but through what Marlow has heard about him.

The chief accountant at the company station is the first who mentions Mr. Kurtz, and he speaks of him in reverent tones. He tells Marlow that in the interior he will undoubtedly meet MR. Kurtz, a "first-class agent" who "send in as much ivory as all the others put together", and that Mr. Kurtz will be "a somebody in the Administration before long." (Conrad, p.32)

At the central station, Marlow' s curiosity is aroused by the hostility the pilgrims hold towards Kurtz, so he asks the brickmaker about him. The brickmaker tells Marlow that Kurtz "is a prodigy" (Conrad, p.39), sent as a special emissary of Western ideals by the Company's directors and bound for quick advancement.

Then, one evening, all by chance, Marlow overhears the conversation between the manager and his uncle. From their conversation, Marlow learns that Kurtz, when waiting at the central station for his appointment, suggested to the manager that "each center should be like a beacon on the road toward better things, a center for trade, of course, but also for humanizing, improving, instruction." (Conrad, p.47) And the manager also recall that about a year earlier Kurtz sent down a huge load of ivory of the highest quality by canoe with his clerk, but Kurtz himself had turned back to his station all by himself after coming 300 miles down the river.

All the incidents, if gathered together, seem to suggest to Marlow that Kurtz, not like the other whites, is a man with a self in his mind and can tell the truth, and that he wants to do something to change the chaos at the hands of the "flabby devil".

Already disgusted with all the folly and absurdity of the rapacious and cruel colonizers along the way to and at the central station, Marlow now feels an intellectual and moral identification with his imaginary picture of Kurtz. This is why Marlow is so eager to go up the river to reach Kurtz. On the one hand, he has for long wanted to dissociate himself from all the doings of his fellow whites; on the other, he wants to have a face-to-face talk with this Kurtz, who can be his friend, and to have a look at how he sticks to truth in Africa and brings civilization to the native people.

But is this mysterious Kurtz behind the veil as good as his words? Marlow must go to see this with his mind's eye. In some sense, Marlow's journey up the Congo River is a process in which the veil upon Kurtz is gradually rent apart and the true Kurtz appears before him.

In the description of the relationship between Marlow and Kurtz, Conrad makes an impression on the reader that the former is an ally of the latter. The brickmaker at the central station says to Marlow: "You are of the new gang- the gang of virtue. The same people who sent him (Kurtz) specially also recommended you." (Conrad, p.39) Marlow himself also, due to the virtues said of Kurtz, feels some affinity to him. But implicitly, Conrad describes Kurtz as the very opposite of Marlow.

As the steamer goes up the river to the inner station, Marlow feels "like traveling back to the earliest beginning of the world". He can hear an occasional "roll of drums behind the curtain of trees," or "a burst of yells, a whirl of black limbs, a mass of hands clapping, of feet stamping, of bodies swaying" (Conrad, p .51), but he does not know if "the prehistoric man was curing us, praying to us, welcoming us - - who could tell?" (Conrad, p.51) Still, he feels a communication of some kind between him and the "prehistoric man": "What thrilled you was just the thought of their humanity —— like yours —— the thought of your remote kinship with this wild and passionate uproar. Ugly. Yes, it was ugly enough; but if you were man enough you would admit to yourself that there was in you just the faintest trace of a response to the terrible frankness of that noise." (Conrad, p.51) Marlow comes to believe that his subliminal responsiveness is an echo of the primitive residues in his own being; it is "truth stripped of its cloak of time, " and man "must meet that truth...with his own inborn strength. " This inborn strength everyone has. It is a part of one's self. Marlow admits there is "an appeal to me in this fiendish row". This appeal is a kind of temptation, which Marlow keeps at bay with "a deliberate belief." (Conrad, p.52)

What is this deliberate belief? From Conrad's life experiences, it can be inferred that it is Buddhism, his version of Buddhism.

When nearing the inner station, Marlow's steamboat is attacked by the natives. From all the signs, Marlow surmises that the attack on the steamboat is not really an attack: "The action was very far from being aggressive- - it was not even defensive, in the usual sense: it was undertaken under the stress of desperation, and in its essence was purely protective." (Conrad, p.59) Protective of what? Marlow wonders. When he arrives at the inner station he learns from the Russian that the attack is protective of Kurtz because the natives adore him, and "they don' $t$ want him to go." The Russian further reveals that it is actually "Kurtz who had ordered the attack" (Conrad, p.81). From this point on, Marlow feels disillusioned and the truth behind the veil all comes to light before him.

Form the Russian, Marlow also learns that to satisfy his greed, Kurtz can do anything. When he has no goods to trade with, he forces with guns the natives of the villages round the lake to follow him to raid other villages for ivory. "He came to them with thunder and lightning (that is guns), you know - - and they had never seen anything like it- - and very terrible." And to get the small lot of ivory owned by the Russian who accompanies and has twice saved him, Kurtz 
simply threatens to shoot him unless he gives him the ivory. "There was nothing to prevent him killing whom he jolly well pleased" (Conrad, p.74). When Marlow discovers with his binoculars the heads of the natives on the top of the posts around Kurtz' s house, he is greatly shocked and throws his "head as if before a blow." (Conrad, p.75) All these, Marlow concludes, "only showed that MR. Kurtz lacked restraint in the gratification of his various lusts, that there was something wanting in him- - some small matter which, when the pressing need arose, could not be found under his magnificent eloquence." (Conrad, p.75-76) That "small matter "is his self.

To Kurtz, vanity is also a great temptation; he "desired to have kings meet him at railway stations on his return from some ghastly Nowhere, where he intended to accomplish great things" (Conrad, p.87) when he comes back to the civilized society.

In Africa, his desire goes uncontrolled. Just as what he says in his report to the International Society for the Suppression of Savage Customs: "... we whites, from the point of development we had arrived at, 'must necessarily appear to them (savages) in the nature of supernatural beings - - we approach them with the might as of a deity... By the simple exercise of our will we can exert a power for good practically unbounded"' (Conrad, p.67), Kurtz comes to the natives with "thunder and lightning" (Conrad, p.74) and"his ascendancy was extraordinary. The camps of these people surrounded the place, and the chiefs came every day to see him. They would crawl..." (Conrad,p76). And "at certain midnight dances ending with unspeakable rites, which... were offered to him... to Mr. Kurtz himself." (Conrad, p.67)

Every desire is a temptation to Kurtz. To be god of the natives is also a temptation, and a great temptation, to which Kurtz totally yields. He becomes the god of the natives and he has got everything to satisfy his greed. But he loses his self in the process. Without a self in his mind, he is "hollow at the core" (Conrad, p.76). Just as he claims "My Intended, my ivory, my station, my..." (Conrad, p.65), everything belongs to him. But things belong to each other. If Kurtz claims every one of his desires, all the devilish powers behind all his desires will in the same way claim him. Their need for each other is equally imperious. This is why "after coming three hundred miles," Kurtz "suddenly had decided to go back, which he started to do alone in a small dugout with four paddlers, leaving the half-caste to continue down the river with the ivory." (Conrad, p.46-47) This is why Kurtz, after being settled down on the boat, "crawling on all fours" at midnight onto the bank and to his tribe men nearby who are "chanting...some weird incantation"(Conrad, p.84)

To sum up, Marlow's journey from Europe to Africa and then up the Congo River to the Company's Inner Station to reach Kurtz can be seen as a process to tear up two veils of Maja. Behind the first veil, he sees the cruelties, absurdities and travesties of administration at the hands of "the flabby, weak-eyed devil" who is avaricious of money and is somewhat lost in Africa. Behind the second veil woven by the whites at the Company in Africa, Marlow finds, as Arthur Schopenhauer puts it, "no God, but Satan." the whites, even though they reach Kurtz together with Marlow, cannot see what Marlow sees. While Marlow sees a soul "like a tree- swayed in the wind" and "utterly lost" (Conrad, p.84) in the wild due to the lack of self, the other whites, represented by the manager, only care about the opportunity to grab ivory and blame Kurtz for his "unsound method" to grab ivory. (Conrad, p.80) These whites, though they are themselves in Africa, cannot see through the veil before them because they, their mind being filled with money or whatever, have lost themselves there and have not the means to get in direct touch with reality.

\section{CONCLUSION}

Though written over a century ago, the novella is still thought-provoking. On the one hand it shows vividly before the modern reader the danger of Mammon worship and gets the reader to have a look into the mind of himself to make sure his self is not lost in this busy world filled with temptations; on the other, the novella illustrates the importance of spiritual values in the world' $s$ life. Never cry "The horror! The horror!" when it is too late. These may be what Conrad meant to tell the reader and are what this paper has tried to interpret.

\section{REFERENCES}

[1] Adams, Richard, Critical Studies: Heart of Darkness. London: Penguin Books, 1991.

[2] Conrad, Joseph. Heart of Darkness and The End of The Tether. New York:Airmont Publishing Company, Inc., 1966

[3] Galworthy, John. Reminiscences of Conrad1924, in his Castles in Spain and other Screeds. New York:Charles Scribner's Sons, 1927

[4] KImbrough, Robert. Joseph Conrad Heart of Darkness, Norton Critical Editions. New York: W.W.Norton and Company, Inc., 1963

[5] Li,Ren \&Yu, Pan, Life and Will--Collections of Schopenhauer, trans. Beijing: Hualing Press, 1997

[6] Russel, Bertrand, History of Western Philosophy, trans. Zhaowu He, Joseph Terence Montgomery Needham, Beijing: The Commercial Press, 2015

[7] Schopenhauer, Arthur, The World As Will and Idea, General Books LLC,2009

[8] Stape, J.H..The Cambridge Companion to Joseph Conrad. Shanghai: Shanghai Foreign Language Education Press,2000

[9] Susanne K. Langer, Feeling and Form, Macmillan Pub Co,1953

[10] Watt, Ian. Conrad in the Nineteenth Century. Berkeley and Los Angeles: University of California Press, 1979

[11] Youlan, Feng, A Brief History of Chinese Philosophy, Bejing : Peking University Press, 2013

[12] Zhongzai Zhang, Fengzhen Wang, Guoxin Zhao, Selective Readings in $20^{\text {th }}$ century western critical theory, Beijing: Foreign Language Teaching and Research Press, 2015. 